\title{
Az Európai Unió Bíróságának jogfejlesztő szerepe a héa rendszerében
}

\section{SZLIFKA Gábor ${ }^{1}$}

\begin{abstract}
Nem túlzás azt mondani, hogy a héa rendszerében az Európai Unió Bírósága a jogértelmezés motorja, a jogharmonizáció őre, ítéleteinek indokolásában olyan irányokat tüz ki, amelyek a jogalkalmazás számára is mértékadók. Fontos ezért tisztázni azt, hogy melyek azok a keretek, amelyek a bíróság e tevékenységét meghatározzák. A következőkben arra vállalkozom röviden, hogy bemutassam azon alapelveket, amelyek alappillérei a bíróság döntéshozatali mechanizmusának a héa rendszerében, illetve betekintést engedjek jogeseteken keresztül, hogy egyedi ügyekben ezen alapelveket hogyan érvényesíti.
\end{abstract}

Kulcsszavak: adó, héa, Európai Unió Bírósága

Az Európai Unió Bírósága kvázi egy szövetségi állam alkotmánybíróságaként ${ }^{2}$ múködik, mivel az EK-szerződés olyan hatáskörrel ruházta fel, ${ }^{3}$ amellyel mind a közösség, mind a tagállamok jogi aktusainak jogszerűségét vizsgálja felül. ${ }^{4}$ Ez a normakontroll hasonlóságot mutat a magyar Alkotmánybíróság eljárásával, amely során az Alkotmánybíróság felülvizsgálja a jogszabályoknak az Alaptörvénnyel való összhangját. A bíróság eljárásai közül a téma szempontjából az előzetes döntéshozatali eljárás kiemelt fontosságú, mivel a héa alkalmazásával kapcsolatos előremutató jogértelmezést és indokolást tartalmazó döntések ezen eljárásban születnek. Elöljáróban megjegyzem, hogy a tagállamoknak lehetőségük van az előzetes döntéshozatali eljárásban való részvételre, így a relevánsnak tartott ügy tárgyalásakor lehetőségük van álláspontjuk kinyilvánítására. Abban az esetben, ha valamely tagállam bíróságának az előtte folyamatban lévő ügy eldöntéséhez szükséges az uniós jog értelmezése, akkor az Európai Unió Bíróságához fordulhat. Ha az adott nemzeti jog szerint az eljáró bíróság döntése ellen már nincs jogorvoslati lehetőség, akkor a nemzeti bíróság köteles az unió bíróságához fordulni. A kérdést előterjesztő nemzeti bíróságnak is megfelelően elvonatkoztatva,

SZLIFKA Gábor dr., ellenőrzési igazgatóhelyettes, Nemzeti Adó- és Vámhivatal Pest Megyei Adó- és Vámigazgatósága Ellenőrzési Igazgatóhelyettesi Szervezet

Gábor SZLIFKA, Deputy Director for Tax Investigation, National Tax and Customs Administration Pest County Tax and Customs Directorate

https://orcid.org/0000-0003-2705-0350; szlifka.gabor@nav.gov.hu

Dezső-Vincze (2012) 372.

3 Az Európai Unióról szóló szerződés (EUSZ) és az Európai Unió múködéséről szóló szerződés (EUMSZ) 263. cikk.

4 C-402/05 és C-415/05. sz. Yassin Abdullah Kadi és Al Barakaat International Foundation kontra Tanács és Bizottság egyesített ügyekben 2008. szeptember 3-án hozott ítélet [EU:C:2008:461]. 
az ügyet absztrahálva kell megfogalmaznia a kérdését, mivel a bíróság nem alkalmazhatja az uniós jogot egyedi esetre vonatkozóan, hanem kizárólag értelmezési útmutatót ad. Ez azt jelenti, hogy a bíróság ténylegesen nem dönti el az adott ügyet, vagyis nem hoz a felekre és a nemzeti bíróságra is kötelező döntést, hanem az ügy fényében értelmezi az uniós jogot. Ez az értelmezés kötelező és a tagállami bíróság köteles ezt az útmutatót figyelembe venni és döntését ez alapján meghozni. Az így megszületett jogértelmezés elvileg minden azonos jogesetre nézve kötelezővé válik, bár sok esetben kétséges, hogy valóban minden tekintetben azonos tényállással szembesül-e a bíróság.

Érdemes ennél a pontnál érinteni a kötőerő kérdését, azaz azt megvizsgálni, hogy az előzetes döntéshozatali eljárásban hozott döntés mennyiben kötelező a felekre vagy harmadik személyre. Dezső Márta és Vincze Attila munkájukban ${ }^{5}$ kizárják az erga omnes hatályt, mivel ebben az esetben az Európai Unió Bírósága lényegében jogalkotói tevékenységgel lenne felruházva, ami a szerződésből nem következik. Nem beszélhetünk inter partes hatályról sem, hiszen a bíróság nem dönti el kötelező módon a felek közötti jogvitát, hanem a kérdést előterjesztő bíróságnak ad kötelező érvényű, általános formában megfogalmazott instrukciót. Ezen eljárás eredményeként döntéseknek egy olyan rendszere jön létre és alakul folyamatosan, amelyet joggal nevezhetünk precedensrendszernek. ${ }^{6}$ Hangsúlyozandó ugyanakkor, hogy a common law jogcsaláddal ellentétben ez a precedensjog nem a stare decisis elve alapján épül fel, ami egyrészt azért is lehetséges, mert az ítéletek nem egy adott esetet bírálnak el a szó szoros értelmében véve, másrészt a tagállami bíróságoknak is van mozgásterük az ítélet meghozatala során. Ez utóbbi lehetőségre most nem térnék ki, mert a héa tárgykörében meghozott ítéletek körében erre nem említhető példa. Hanák András az Egyesült Államokban müködő precedensrendszerről írt tanulmányában ${ }^{7}$ érinti azon fogalmakat, amelyek a kevésbé nagy múltú európai rendszerre is jellemzőek. Az Európai Unió Bíróságának döntései között ugyanúgy előfordul a „well settled precedent” típusú ügy, amely a töretlen bírói gyakorlat meghatározással feleltethető meg, és értelmezhetőek a „distinguishing” és „overruling” fogalmak is. Az utóbbi két folyamat az ügyek alapját képező releváns tények eltérő volta esetén jöhet szóba, amelyek a bíróságot az általános iránytól való eltérésre vagy teljes irányváltásra késztetik. Ehhez az ügyek bizonyos tipizálható csoportjait kell alapul venni és analízisnek alávetni. Azon túlmenően, hogy az egyes döntések kötelező jogalkalmazást jelentenek a tagállamok számára, fontos kiemelni, hogy az ítéletek indokolásában rögzített alapelveknek és a héa témában kialakult európai értelemben vett precedensjog logikai rendszerének legalább ugyanolyan jelentősége van.

A bíróság héarendszert érintő és alakító döntéseit természetesen nem az adott esetet önmagában szemlélve hozza meg, hanem azok beleilleszkednek egy történeti-logikai folyamatba, így elméleti szinten a jogesetek egy koherens rendszert alkotnak.

Dezső-Vincze (2012) 392.

Juhász (2014) 375.

Hanák (2012) 
Ez a bíróság által alkalmazott úgynevezett rendszertani módszer. ${ }^{8}$ A másik releváns jogértelmezési módszer a teleologikus, amely során a döntés alapjául szolgáló tényállásokat a bíróság alapelvi tesztnek veti alá és ennek tükrében alakítja ki korábbi döntéseihez következetesen kapcsolódó álláspontját. Természetesen az ítéleteknek keretet adó alapelvi taxáció nem létezik, az alapelvek a héarendszer és ezen keresztül az ítéletek logikai rendszerének tartópillérei, amelyek következetesen érvényesítik a jogalkotói akaratot. Englisch szerint az egyenlő bánásmód alapvető vezérelv az adózásban, amenynyiben ez a jogalkotót is köti és bírósági felülvizsgálat során is zsinórmértékül szolgál. ${ }^{9}$ Más álláspont szerint a héarendszer három alapelve az adósemlegesség, a közösségi joggal való visszaélés tilalma ('fraus legis'), valamint az adócsalás tilalma. ${ }^{10} \mathrm{~A}$ bíróság által következetesen alkalmazott és folyamatosan értelmezett alapelvek a teljes héarendszert alkotó szabályokból kikristályosodott irányjelzői a jogalkalmazásnak, amelyek összegyưjtésére és rövid bemutatására teszek kísérletet a következőkben. Az alapelvek határait általánosságban nyilvánvalóan nem lehet kijelölni, azok csak az egyes ügyeket illetően tárhatók fel. A következőkben néhány példát igyekszem bemutatni, amely közelebb visz a megfelelő szemlélet kialakításához. Célom ezen keresztül annak szemléltetése, hogy az alapelvek tartalmának kitöltése egy folyamat, amely változás az egyes ügyekben hozott döntésekben materializálódik, így többéves távlatban bizonyosan eltérő szemléletet eredményez akár a tagállami adóhatóságok, akár adózók eljárásában.

A héa területén érvényesülő legfontosabb és minden ítéletet átszövő vezérelv az adósemlegesség elve. Az adósemlegesség elve lényegében az egyenlő bánásmód adójogi leképeződése, ami azt követeli meg a tagállamoktól és a jogalkalmazóktól, hogy az adózókkal szemben ne alkalmazzanak eltérő bánásmódot az egymással versenyző termékértékesítések és szolgáltatásnyújtások megítélése kapcsán. Rendkívül fontos ezen elv érvényesítése nemcsak a jogi értelemben, hanem azért is, mert az ügyletek eltérő kezelése jelentős versenytorzító hatással is jár. Az adó semlegességét a jogalkotásnak biztosítani kell, mivel a piac önszabályozása azt nem képes megteremteni és fenntartani. ${ }^{11} \mathrm{Az}$ adólevonási jog területén - amely ügyekben talán a legtöbbet hivatkozik a bíróság az adósemlegességre - ez azt jelenti, hogy a közös héarendszer valamennyi gazdasági tevékenység adóterhét illetően semleges, azaz az adóalanyokat teljes egészében mentesíti minden gazdasági tevékenysége során felszámított és megfizetett adó terhe alól. Bizonyosan nem kizárólag a személyes álláspontom az, hogy a bíróság tevékenysége során a semlegesség elvének határait folyamatosan bővíti, ezen elv érvényesítésének térnyerése jelentős aszimmetriához vezet(het) az adójogviszonyt illetően.

Erdős-Földes-Őry (2013) 63.

Englisch (2009) 5. „Finally, the guiding principles of a tax may become relevant if there is a principle of equal treatment in the respective legal system which is binding also upon the legislator and subject to some form of judicial review. The fundamental principles of taxation and their more specific subordinate principles will then become the relevant yardstick or tertium comparationis for assessing the equality of taxation, since they must be implemented in a coherent and sonsistent manner."

10 Doesum-Kesteren-Norden (2016) 35-43.

11 Kolozs (2009) 203. 
A témában említeném a magyar vonatkozású PARAT-ügyet, ${ }^{12}$ amelyben - és azt megelőzően meghozott több ítéletben ${ }^{13}$ is - a bíróság kinyilvánítja, hogy minden olyan nemzeti szabályozást, amely az adólevonási jog közösségi előírásaitól való eltérést szabályoz, szigorúan kell értelmezni, hogy az egyértelműen priorizált adósemlegességet biztosítani lehessen. Ezen elv más viszonylatban a kivételek megszorító értelmezését követeli meg. A PFC Clinic-ügyben ${ }^{14}$ a bíróság hangsúlyozta az orvosi gyógykezelés és egészségügyi ellátás fogalmának tisztázásához, hogy „az adómentességek leírására használt kifejezéseket szigorúan kell értelmezni, mivel ezek kivételt jelentenek a fő szabályhoz képest, miszerint az adóalany által ellenszolgáltatás fejében teljesített minden termékértékesítés és szolgáltatásnyújtás után héát kell fizetni”.

Kiállta az adósemlegesség próbáját a Vámos Dávid-ügy ${ }^{15}$ alaptényállása, amelyben a magyar adóhatóság megállapította, hogy adózó online platformon keresztül úgy végzett folyamatos gazdasági tevékenységet, hogy azt az adóhatósághoz nem jelentette be. Az értékesítéseivel azonban nem érte el az alanyi mentesség értékhatárát, ezért az adóhatósági megállapítást követően élni kívánt volna vele, azaz utólag, azt követően, hogy fény derült az adóelkerülő magatartására. A magyar adóhatóság ezt a kérést elutasította azzal az indokolással, hogy a magyar szabályozás erre csak az adóköteles tevékenység bejelentésével egyidejúleg ad lehetőséget. ${ }^{16}$ A magyar adóhatóság döntését az Európai Bíróság mind az adósemlegesség, mind a jogbiztonság elvével összeegyeztethetőnek találta. Ez utóbbi megállapítását - többek között - azzal is alátámasztotta indokolásában, hogy az adóalany adójogi helyzete ne lehessen meghatározhatatlan ideig vitatható, amit a magyar szabályozás egyértelmúvé is tett.

A bírósági gyakorlat által kialakított és az adósemlegességhez kapcsolódó fontos jogelv az adósemlegesség tényleges érvényesülésének elve. Ez az unió bíróságának ítéleteiből levezethető követelmény a tagállami jogalkalmazás felé, amelynek a célja az, hogy a héarendszer alapelvét, az adósemlegesség elvét minden esetben érvényre juttassák, és különösen a nemzeti bíróságok az előttük folyamatban lévő ügyek elbírálása során biztosítsák az uniós jog teljes érvényesülését. Ez azt az elvárást jelenti, hogy a megfelelően pontos tagállami szabályozás, vagyis a meglévő pozitív jog ellenére vagy azt felülírva is az uniós jogot érvényesítsék. Ennek egyik megnyilvánulása olvasható a bolgár Rusedespred-ügyben. ${ }^{17}$ Ebben az ügyben a bolgár adóhatóság megtagadta adózó által partnere részére felszámított adó helyesbítését annak okán, hogy az adóhatóság a part-

12 C-74/08. sz. PARAT Automotive Cabrio Textiltetőket Gyártó Kft. és az Adó- és Pénzügyi Ellenőrzési Hivatal Észak magyarországi Kihelyezett Hatósági Osztály között folyamatban lévő ügyben 2009. április 23-án meghozott ítélet [EU:C:2009:261] 23. pontja.

13 Így a C-414/07. sz. Magoora-ügyben 2008. december 22-én hozott ítélet [EU:C:2008:766] 28. pontja, valamint C-409/99. sz. Metropol és Stadler-ügyben 2002. január 8-án hozott ítélet [EU:C:2002:2] 59. pontja.

14 C-91/12. sz. Skatteverket és a PFC Clinic AB közötti eljárásban 2013. március 21-én meghozott ítélet [EU:C:2013:198] 23. pontja.

15 C-566/16. sz. Vámos Dávid-ügyben 2018. május 17-én hozott ítélet [EU:C:2018:321].

16 Régi Art. 22. § (1) bekezdésének c) pontja.

17 C-138/12. sz. Rusedespred OOD és a Direktor na Direktsia „Obzhalvane i upravlenie na izpalnenieto” - Varna pri Tsentralno upravlenie na Natsionalnata agantsia za prihodite között 2013. április 11-én meghozott döntés [EU:C:2013:233]. 
ner által befogadott számla héaösszegének levonását elutasította a gazdasági esemény adómentessége miatt. A nemzeti jog alapján - az adóhatóság döntése miatt - már nem volt mód a helyesbítésre. A bíróság ezt az adósemlegesség elvébe ütközőnek találta, és hangsúlyozta, hogy az adózó hivatkozhat az adósemlegesség elvére az azt megsértő nemzeti joggal vagy joggyakorlattal szemben. Ez biztosítaná, hogy az adósemlegesség a nemzeti jogon felül álló alapelvként érvényesülhessen. A PORR-ügyben ${ }^{18}$ hozott ítélet középpontjában a fordított adózás alkalmazása állt, adózó egyenes adózás alapján kiállított számlán szereplő adót helyezett levonásba annak ellenére, hogy a szolgáltatásra a fordított adózás lett volna alkalmazandó. Ilyen esetben a költségvetésnek megfizetett adó a számlakibocsátónak, az ellenérték részeként megfizetett adó a számla befogadójának jár vissza. A számla korrekciója és az ennek megfelelő „visszatérítési láncolat” azonban akadályba ütközhet, ha a számlakibocsátó megszűnt, fizetésképtelen vagy ellenőrzéssel lefedett időszakkal érintett, így módosításra már nincs lehetőség. „A tényleges érvényesülés elvének tiszteletben tartása megköveteli a tagállamok részéről olyan eszközök és eljárási szabályok bevezetését, amelyek lehetővé teszik, hogy a szolgáltatás említett igénybe vevője visszaigényelhesse a jogalap nélkül felszámított adót." ${ }^{19}$ A magyar áfatörvény ilyen distinkciót nem ismer, az ítélet institúciója leginkább az adóhatósági gyakorlat útján valósul meg. ${ }^{20}$

A pénzügyi következményekkel járó adójogi döntésekben fokozottan kell érvényesülnie a jogbiztonság elvének. ${ }^{21} \mathrm{~A}$ jogbiztonság elvének alkalmazása és a bíróság által a jogszerűség fokmérőjekénti figyelembevétele már a héarendszer létrejötte óta kíséri a bírósági döntéseket. Az európai héarendszerben azt jelenti, hogy a tagállami jogszabályokat egyértelműen kell megfogalmazni annak érdekében, hogy lehetôvé tegyék az érintett személyek számára, hogy jogaikat és kötelezettségeiket világosan és pontosan ismerjék, valamint a nemzeti hatóságok biztosítani tudják a tiszteletben tartásukat. ${ }^{22} \mathrm{~A}$ jogbiztonság alapelve számos egyéb, a héaszabályozásban és jogalkalmazásban megnyilvánuló származtatott elv forrása és kiinduló pontja. Elsőként az adózó jogi helyzetének vitathatóságának időbeli korlátozására vonatkozó lényeges elvet említem. Ez azt jelenti, hogy a nemzeti adóhatóságok számára nem áll rendelkezésre meghatározhatatlan idő az adózó adójogi helyzetének megkérdőjelezésére. ${ }^{23}$ Adózó számára a jogbiztonság azt is jelenti, hogy nincs kitéve az egyes ügyletek minősítésének vagy

18 C-691/17. sz. Porr Építési Kft. kontra NAV Fellebbviteli Igazgatósága közötti ügyben 2019. április 11-én hozott ítélet [EU:C:2019:327].

19 C-691/17. sz. Porr Építési Kft. kontra NAV Fellebbviteli Igazgatósága közötti ügy ítéletének 42. pontja.

20 Kotánczi (2019) 26.

21 Ahogy a Bíróság a C-181/04-C-183/04. sz. Elmeka NE és Ypourgos Oikonomikon közötti egyesített ügyekben 2006. szeptember 14-én hozott ítéletben [EU:C:2006:563] kifejti, „a Bíróság állandó ítélkezési gyakorlata szerint a jogbiztonság és a bizalomvédelem elvét az Európai Unió intézményeinek, de az uniós irányelvek által rájuk bízott hatáskörök gyakorlása során a tagállamoknak is tiszteletben kell tartaniuk".

22 C-257/86 sz. Bizottság kontra Olaszország közötti eljárásban 1988. június 21-én hozott ítélet 12. pontja [EU:C:1988:324].

${ }^{23}$ C-424/12. sz. SC Fatorie Srl és a Directia Generala a Finantelor Publice Bihor közötti ügyben 2014. február 6-án meghozott ítélet [EU:C:2014:50] 46. pontja Az ítéletben a bíróság ugyanakkor elismerte, hogy a jogvesztő határidőben az adóhatóság által jóváhagyott levonási jogot elismerő döntés módosítása és a jog elvitatása nem ütközik a jogbiztonság elvébe. 
átminősítésének örökös kockázatának. A bíróság más ítéletben ${ }^{24}$ is megerősítette, hogy ez a határ az elévülési idő, vagyis adózó terhére meghozott vagy módosított döntés az elévülési időn belül meghozható, és nem ütközik a jogbiztonság elvébe. A bíróság a jogbiztonság elvét érvényesítette a magyar állammal szemben a Humán Operátorügyben, ${ }^{25}$ amelynek lényege az volt, hogy Magyarország az irányelv 193. cikke alapján eltérő szabályt vezetett be és fordított adózást rendelt alkalmazni 2015. január 1-jétől bizonyos humán erőforrás kölcsönzésére irányuló szolgáltatásokra. ${ }^{26} \mathrm{Az}$ általános szabálytól való eltérést engedélyező végrehajtási határozatról azonban csak 2015. december 11-én értesítették a magyar kormányt, ezért a szabály január 1-jétől történő alkalmazása ellentétes az irányelvvel. ${ }^{27}$ Vagyis adózó a befogadott számlákban felszámított adó levonására jogosult az általános szabályok szerint, amelyet az adóhatóság elvitatott. A bíróság a jogbiztonság érvényesülését abban látta, hogy a jogi rendelkezéseknek egyértelműeknek és pontosaknak, hatásaiknak pedig előreláthatóaknak kell lenniük, ${ }^{28}$ amely ebben az ügyben nem érvényesült.

A jogbiztonsággal határos és a jogalkalmazásba beépült, de nem ugyanazon tőről fakadó alapelv a bizalomvédelem elve, amely elsősorban az adózókat megillető védelem a nemzeti adóhatóság valamely aktusára alapuló adójogi eljárását illetően. Ez nem elsősorban valamely jogforrásra épülő biztosíték adózó részéről, hanem egyfajta várományt keletkeztet adózó részére a hatóság valamely aktusa, eljárása alapján. A bíróság egy nem adóügyben meghozott döntésében ${ }^{29}$ úgy fogalmazott, hogy a bizalomvédelemre mint „jogra történő hivatkozás joga minden olyan jogalanyt megillet, akiben valamely közigazgatási hatóság megalapozott várakozásokat keltett a részére tett pontos ígéretek folytán”. A bizalomvédelem akkor válik alkalmazandó elvvé, ha a közigazgatási aktus „észszerú bizalmat” kelt az egyébként kellő körültekintéssel eljáró adózó tudatában. Az észszerű bizalom egy objektív megnyilvánulás bizonyos adójogi következmények levonására és alkalmazására, ami egy egyértelmúen értelmezhető hatósági iránymutatást vagy döntést jelent. A Salomie-ügyben ${ }^{30}$ a bíróság nem fogadta el adózó azon érvelését, hogy az adóhatóság addigi gyakorlata őt támasztja alá, azaz az adóhatósági gyakorlat nem minősül ilyen észszerú bizalmat megalapozó hatósági magatartásnak.

Szintén alapvető jogelv az arányosság alkalmazása a tagállamok jogalkotása során. Az arányosság azt jelenti, hogy a korábban vázolt, az adósemlegességre épülő héarendszerben a tagállamok rendelkeznek bizonyos mozgástérrel a költségvetési bevételek

24 C-183/14. sz. Radu Florin Salomie és Nicolae Vasile Oltean kontra Directia Generala a Finantelor Publice Cluj ügyben 2015. július 9-én hozott döntés [EU:C:2015:480] 42-43. pontja.

25 C-434/17. sz. Humán Operátor Zrt. és a Nemzeti Adó- és Vámhivatal Fellebbviteli Igazgatósága között folyamatban lévő ügyben 2019. február 13-án hozott ítélet [EU:C:2019:112].

26 Áfatörvény 142. § (1) bekezdés c) pontjával.

27 2006/112/EK irányelv közös hozzáadottérték-adó rendszeréről.

28 C-183/14. sz. Radu Florin Salomie és Nicolae Vasile Oltean kontra Directia Generala a Finantelor Publice Cluj ügy ítéletének 34. pont.

29 C-585/13. sz. az Europäisch-Iranische Handelsbank AG és az Európai Unió Tanácsa között folyamatban lévő eljárásban 2015. március 5-én meghozott ítélet [EU:C:2015:145] 95. pontja.

30 C-183/14. sz. Radu Florin Salomie és Nicolae Vasile Oltean kontra Directia Generala a Finantelor Publice Cluj ügyben 2015. július 9-én hozott döntés [EU:C:2015:480]. 
biztosítását és az adócsalások megelőzését célzó intézkedések megválasztásában, azonban ezt a diszkrecionális jogkörüket a fentiek mellett az arányosság szem előtt tartásával kell gyakorolniuk. Ezen intézkedések azonban nem haladhatják meg azt a szükséges mértéket, amely azok céljának eléréséhez elegendő. A bíróság egy döntésében ${ }^{31}$ úgy fogalmaz, hogy a tagállamok intézkedései irányulhatnak ugyan az államkincstár érdekeinek leghatékonyabb védelmére, azonban ezen intézkedések nem terjedhetnek túl az e célhoz szükséges mértéken. Az arányosság mércéjét a bíróság általában a szankciók megítélésekor, illetve szankcióként alkalmazott intézkedések esetében alkalmazza. Az arányosság elvének alkalmazása nem kizárólag az anyagi jogi szabályok európai harmonizációjának fokmérőjeként kerül alkalmazásra az ítélkezési gyakorlatban, hanem a tagállami adóhatóságok eljárásának vizsgálatakor is. A szintén magyar érdekeltségú WebMindLicences ${ }^{32}$ ügyben a bíróság az arányosság elvét alkalmazta a büntetőeljárásban beszerzett bizonyítékok felhasználhatóságának vizsgálatakor. A konkrét ügyben a büntetőeljárás részeként készült telefonlehallgatások és lefoglalt elektronikus levelezés felhasználása vetette fel azt a kérdést, hogy szükségesek-e a tényállás feltárásához, azaz arányos intézkedésnek minősülnek-e. A Bíróság az Európai Unió alapjogi Chartájának követelményeivel szembeállítva csak indokolt körülmények fennállása mellett és szigorú garanciális szabályok ${ }^{33}$ betartása mellett látta jogszerűnek az egyébként még be sem fejeződött büntetőeljárásban felvett bizonyítékok alkalmazhatóságát.

Az anyagi és eljárási szabályozás a közösségi héarendszerben nem ugyanazon kézben van. Míg az anyagi szabályozás az irányelven és más szabályzókon keresztül főként az uniós szervek hatáskörében van, addig a tagállamok az eljárásjog jelentős részében autonómiát élveznek. Logikus követelmény egy ilyen rendszerben az, hogy az eljárásjognak segítenie kell az anyagi jog érvényesülését függetlenül attól, hogy annak megalkotására uniós szinten vagy tagállami szinten került-e sor. A bíróság ítélkezési gyakorlatából kiolvasható követelmény a fentieken túlmenően az egyenértékűség elve, amely azt követeli meg a tagállamoktól, hogy ne legyen eljárásjogi különbség az uniós és hazai anyagi jogi szabályok tényleges érvényesíthetősége között.

\section{IRODALOMJEGYZÉK}

Dezső Márta - Vincze Attila (2012): Magyar alkotmányosság az európai integrációban. HVG-ORAC Lapés Könyvkiadó.

Doesum, Ad van - Kesteren, Herman van - Norden, Gert-Jan van (2016): Fundamentals of EU VAT Law. The Netherlands, Wolters Kluwer.

31 C-384/04. sz. Comissioners of Customs and Excise és a Federation of Technological Industries és társai közötti eljárásban 2006. május 11-én hozott ítélet [EU:C:2006:309] 30. pont.

32 C-419/14. sz. WebMindLicences Kft. és a Nemzeti Adó- és Vámhatóság Kiemelt Adó- és Vám Főigazgatóság közötti perben 2015. december 17-én meghozott döntés [EU:C:2015:832] 61-91. pontjai.

33 A hivatkozott ítélet alapján ilyen garanciális szabály ezen bizonyítási eszközök adózó általi megismerhetősége, illetve a határozat meghozatala előtti meghallgatása, valamint ezen bizonyítékok megszerzése jogszerűségének vizsgálata a közigazgatási döntést felülvizsgáló bíróság részéről. Amennyiben ezen feltételek nem teljesülnek, akkor az adóhatóságnak ezen bizonyítékokat ki kell zárnia. 
Englisch, Joachim (2009): VAT/GST and Direct Taxes: Different Purposes. In Lang, Michael - Melz, Peter - Kristofferson, Eleonor eds.: Value Added Tax and Direct Taxation - Similarities and Differences. IBFD. 5.

Erdős Gabriella - Földes Balázs - Őry Tamás (2013): Az Európai Unió adójoga. Budapest, Wolters Kluwer. Hanák András (2012): A precedenstan az Amerikai Egyesült Államokban. Jogesetek Magyarázata, 2. sz. 77-80. Forrás: https://jema.hu/article.php?c=167 (2019. 12. 01.)

Juhász Endre (2014): Magyarország és az Európai Unió Bírósága. Közgazdasági Szemle, 61. évf. 4. sz. 373-390.

Kolozs Borbála (2009): Neutrality in VAT In Lang. In Michael - Melz, Peter - Kristofferson, Eleonor eds.: Value Added Tax and Direct Taxation - Similarities and Differences. IBFD. 203.

Kotánczi Zsófia (2019): Az adóhatóság gyakorlata jogosulatlanul áthárított áfa esetén. Számvitel, Adó, Könyvvizsgálat, 61. évf. 6. sz. 25-26.

\section{Jogforrások}

2006/112/EK irányelv közös hozzáadottérték-adó rendszerről

Az Európai Unióról szóló szerződés (EUSZ) és az Európai Unió müködéséről szóló szerződés (EUMSZ)

C-138/12. sz. Rusedespred OOD és a Direktor na Direktsia „Obzhalvane i upravlenie na izpalnenie-

to" - Varna pri Tsentralno upravlenie na Natsionalnata agantsia za prihodite között 2013. április 11-én meghozott döntés [EU:C:2013:233]

C-181/04-C-183/04. sz. Elmeka NE és Ypourgos Oikonomikon közötti egyesített ügyekben 2006. szeptember 14-én hozott ítéletben meghozott ítélet [EU:C:2006:563]

C-183/14. sz. Radu Florin Salomie és Nicolae Vasile Oltean kontra Directia Generala a Finantelor Publice Cluj ügyben 2015. július 9-én hozott döntés [EU:C:2015:480]

C-257/86 sz. Bizottság kontra Olaszország közötti eljárásban 1988. június 21-én hozott ítélet [EU:C:1988:324]

C-384/04. sz. Comissioners of Customs and Excise és a Federation of Technological Industries és társai közötti eljárásban 2006. május 11-én hozott ítélet [EU:C:2006:309]

C-402/05 és C-415/05. sz. Yassin Abdullah Kadi és Al Barakaat International Foundation kontra Tanács és Bizottság egyesített ügyekben 2008. szeptember 3-án hozott ítélet [EU:C:2008:461]

C-409/99. sz. Metropol és Stadler-ügyben 2002. január 8-án hozott ítélet [EU:C:2002:2]

C-414/07. sz. Magoora-ügyben 2008. december 22-én hozott ítélet [EU:C:2008:766]

C-419/14. sz. WebMindLicences Kft. és a Nemzeti Adó- és Vámhatóság Kiemelt Adó- és Vám Főigazgatóság közötti perben 2015. december 17-én meghozott döntés [EU:C:2015:832]

C-424/12. sz. SC Fatorie Srl és a Directia Generala a Finantelor Publice Bihor közötti ügyben 2014. február 6-án meghozott ítélet [EU:C:2014:50]

C-434/17. sz. Humán Operátor Zrt. és a Nemzeti Adó- és Vámhivatal Fellebbviteli Igazgatósága között folyamatban lévő ügyben 2019. február 13-án hozott ítélet [EU:C:2019:112]

C-566/16. sz. Vámos Dávid-ügyben 2018. május 17-én hozott ítélet [EU:C:2018:321]

C-585/13. sz. az Europäisch-Iranische Handelsbank AG és az Európai Unió Tanácsa között folyamatban lévő eljárásban 2015. március 5-én meghozott ítélet [EU:C:2015:145]

C-691/17. sz. Porr Építési Kft. kontra NAV Fellebbviteli Igazgatósága közötti ügyben 2019. április 11-én hozott ítélet [EU:C:2019:327]

C-74/08. sz. PARAT Automotive Cabrio Textiltetőket Gyártó Kft. és az Adó- és Pénzügyi Ellenőrzési Hivatal Észak magyarországi Kihelyezett Hatósági Osztály között folyamatban lévő ügyben 2009. április 23-án meghozott ítélet [EU:C:2009:261] 23. pontja

C-91/12. sz. Skatteverket és a PFC Clinic AB közötti eljárásban 2013. március 21-én meghozott ítélet [EU:C:2013:198] 


\section{ABSTRACT \\ The Role of the Court of Justice of the European Union in the Development of the VAT System}

SZLIFKA Gábor

It is not an exaggeration to say that, in the VAT system, the Court of Justice of the European Union is the main driver of legal interpretation and the guardian of legislative alignment. In its judgments it sets out the guidelines that serve as standards for the application of the law. It is therefore important to understand the framework that determines the Court's activities. In the following, I will briefly introduce the principles which are the cornerstones of the Court's decision-making mechanism in the VAT system and I will give insight into how these principles are applied in individual legal cases.

Keywords: tax, VAT, European Court 